\title{
NOVEL STUDY IN LEARNING HISTORY (Descriptive Analytical Study of the Ability of the History Education Department Students in Appreciating Novel)
}

\author{
Wildan Insan Fauzi ${ }^{1}$
}

\begin{abstract}
The background of this study is the writer's concern about history learning which only focus on rote learning and text book that makes the student drown into the sea of facts. Therefore, it is true what Tolstoy said that history is nothing but useless collection of stories which aimed is only for "entertainment". In fact, the aim of Novel study can balance the intellectual side and the value learning, give a better chance to remind various history facts, and make history learning become more enjoyable. However, these purposes need to be supported by the history teacher's ability in appreciating historical novel. The focus of this paper is "how good is the History Education Department students appreciating novel in history learning?" This research study used qualitative approach to find a complex and holistic picture about the subject being studied. Besides, the researcher also uses the phenomenology approach which is used in understanding how the students sense their experience when studying the novel and use to observe the perception, ideas, imagination, emotion, desire, willingness, and action they showed when they analyse the historical novel.
\end{abstract}

Key words: historical novels, reception theory, phenomenology, literature appreciation

\section{Introduction}

History, as revealed by Taupik Abdulah (1999), stored precious experience which could give wisdom. Therefore, history is important to learn in order that somebody could earn some boons from the events in the past. The oppinion was subject strengthen by Sam Wineburg (2007: 6) stating that history needs to be taught at schools since it is potential to mould human to be more humane, which is not applied by all other learning curriculums at schools. Without history, past events would merely be used for sole practical importance and we would become separated or disconnected from various life experiences of human. (P.J. Lee, 1984: 5).

However, in the practice, there occurred some problems in learning history as well as in writing history in textbooks. In learning history, the enhancement of intellectual ability (cognitive sphere) in material rote became the primary purpose while the value learning (affective sphere) was neglected,

\footnotetext{
${ }^{1}$ Wildan Insan Fauzi, lecturer of in Social Studies Department in STKIP Pasundan. For academic interest, the author can be contacted through the office address: Permana Street, No 32B, Cimahi, West Java, and email address: historia_wildan@yahoo.com.
} 
whereas its value content was very significant in history. (Wiriaatmadja, 2002: 149). The education in Indonesia recently tends to rely more on cognitive intuition without paying attention to the development of other aspects which are able to support brain performance. This habit happens continuously that triggers Indonesian students to have capability only in 'memorizing' or 'imitating' instead of having ability in solving new problems. Until now, textbooks are the primary source used by the teachers in the learning process in the classroom. As the textbook provides more about facts, it makes the students be drowned in the ocean of facts. It causes the students to be saturated in reading the textbooks and it is worsened by the condition of the textbooks language, it is flat and less emotive. So, how could history purposes be achieved if the history itself was reduced and created to be merely collection of facts?

Thus, it is true what Tolstoy revealed, he viewed that that history was not more than a merely useless collection of stories (Suherti, 2010). Tolstoy desired the existence of a discourse about universal and philosophical past events, not solely to bustle oneself with particulate and dry matters functioning as a mere "dreadnaught or consolation" (Tadjudin, 2004, Suherti, 2010). It is similarly uttered by Foucolt (Saruf, 2008:89-91) who regarded that history is not only glued by the "celebration" of leaders and big events but also neglected ordinary events.

Tolstoy point of view was reposed to write reflective history about human's scrimmage with their fate, it was in the form of historical novels. It was similarly done by Sir Walter Scott who regarded that history often seemed to be "artificial" that he wrote Waverley. This was the first historical novel published in 1810. Sir Walter wholly took up
Alasdair Ranaldson MacDonell's character (1771-1828), a warrior who was almost not recorded in the long history of Scotland clan, as a figure named Fergus Mac-Ivor. Since then, many people wrote factual figures and factually existing places into a novel. Victor Hugo, Alexander Dumas, Charles Dickens were main European authors who reconstructed fact into fiction (Bagja Hidayat, 2009).

The usage of historical novels in learning process is an approach which improves thinking skill as well as affective domain. According to a research, a factor which makes history seems to be "boring" is because the student does not involve his emotion as much as their thought while learning (Sarah Heartz, 2009: 3). When the student uses his emotion as well as his thought in learning, he will feel excated in learning history (Heartz, 2009: 4). As stated by Kama Abdul Hakam (2000: 40) that learning without the existence of emotion element effect would not affect behavior, hence the education system putting aside feeling and emotion was truly ineffective.

Historical novels could help the educators of history to fulfill the shortage and dig up social facts or mental facts which were recorded in the document sources. Even information from literary works could be a guidance for the historian to track farther about "the factual events" through further investigation. Henceforth, the historian along with the history educators need to learn literary works including novels in order to comprehend society's portraits in their era.

History learning using novel study would be able to achieve the desired goal if started and supported by the teachers' ability in appreciating the novels. The students majoring HistoryEducation whoareprepared 
to be teacher (educators) are expected to posses capability of appreciating novels and understand the usage of the novels in learning history at schools optimally. Appreciation as a term in art and literature field actually refers more to activities to comprehend, to interpret, to evaluate, and finally to produce something that similar with the works appreciated. Therefore, appreciation activity is not only receptive: accepting something passively; but also the most important is the appreciation which is productive: produce something actively (Tarigan, 1995: 84). The effort to appreciate literary works cannot be separated from reading matter. Aminudin (2009: 20) proposed two reading concepts which correlated to literary appreciation, namely; aesthetic reading and critical reading. Aesthetic reading is reading an activity which is based on the purpose of enjoying and appreciating the beauty elements which are exposed in a literary texts. Critical reading does not only purpose to understand, to relish, and to enliven, but also to evaluate.

The problem formulation in this research in general is "How is the ability of the History Education Department Students in Appreciating Novel in history learning?. Due to the broadness of the problem formulation, the writer arranged it into the following research questions;

1. How is the students' ability in appreciating aspects associated with history materials contained in historical novels?

2. How is the construction of reality respected to the ability of the History Education Department students in appreciating novels?

3. What are the weaknesses of the History Education Department students in studying historical novels?
4. What efforts can be done to improve ability of the History Education Department students in appreciating historical novels?

\section{Reseach Methodology}

This research applied quantitative approach, started from data and ended with a conclusion. The qualitative research methodology the writer meant was as what Bogdan and Taylor stated (1982:1-2), they defined thatqualitativeresearchmethodology was a research procedure which resulted descriptive data in form of written or spoken words from and of behavior which could be observed. The purpose of this research was to find out complex and holistic description about a problem studied; in this case, it was about the ability of History Education Department students in appreciating novels. Qualitative approach emphasized on the inner significance and comprehension (verstehen), reasoning, the definition of a certain situation (in certain context), tended to study more on thing correlated to daily lives and fundamentally depended on human observation in their own surrounding and associated with the human themselves in their language and their terms or naming. (Creswell, 1998: 2, Moleong, 2006: 2).

Qualitative research aimed at doing an interpretation towards social phenomena. The researcher applied phenomenolgy approach. For the adherents of this paradigm, social reality which becomes the research object does not have their own the quality of tangible social behavior, but it can also an entirely symbolic cultural significance inclduing tangible actions. The researcher used phenomenology approach in the process of data collecting while oserving, interviewing as well as while sharing the 
questionaires and assuming the available data. The researcher applied phenomenology to dig up perception, thoughts, imaginations, emotions, desire, wills, and their perception while they are analyzing the historical novels. Henceforth, the researcher would find data about their perception while analyzing the historical novels and its application in learning, the effect of analyzing historical novel towards students' perception about history and history learning, students' weaknesses analyzing the historical novels as well as some triggered factors.

The researcher observed, browsed, and watched the efforts of history learning done through studying historical novels. The targets or the research objects are limited so that the data obtained could be dug up as much as possible and so that the widening research object didn't occur in finding the research result. Therefore, the credibility of the research itself would determine the quality of the researchi (Bungin, 2001:26). Phenomenology is associated with the significance of life experience for individual or social group. Phenomenology, by borrowing Creswell's definition (1998:51) is an effort to explore awareness structure in human's life. This effort will be used in studying point of view, significances, and values about social reality described in historical novels along with point of views of students who study various social reality described in those novels.

The main objective of phenomenology is to learn how the phenomena faced in awareness, thought, and in actions, such as how the phenomena are valued or accepted aesthetically or in the other words how the students comprehend their experience through themselves. Thus, the phenomenology is used to investigate how the students comprehend, conceive, enliven their experience, read and study the historical novels which aim to understand the history more and useful to history learning. Phenomenology studies the relationship between awareness and the object in order to be able to define and to classify various types of mental phenomena both perception, and opinion as well as emotion. Henceforth, phenomenology is a method in studying the process of students' understanding towards historical novels they are reading and studying.

Phenomenology tries to comprehend informants' understanding towards phenomena occurring in their awareness while they are studying the novels both in the form of perception about historical novels and in the form of students' perception about the usage of novels in learning history. Through phenomenology, the writer expects to comprehend their understanding towards the novels from the students point of view (the persons who directly experience it) or something which is associated with natural human's experiences, and the understanding attached to themselves.

\section{Research Subjects and Setting}

This qualitative research is tried to be carriedoutinHistoryEducationDepartment FPIPS UPI Bandung. The researcher chose this place by several reasons. First. History Education Department FPIPS UPI in its curriculum contains "Literature in History Learning" lecture, taught by Prof. Dr. Rochiati Wiriaatmadja, MA, and Dr. Nana Supriatna, M,Ed. And also "The History of National Movement of Indonesia" lecture, taught by Prof. Dr. Dadang Supardan M.Pd, Drs. Ayi Budi Santosa, M.Si, and Encep Supriatna, M.Pd. Second, learning 
process in these lectures use the analysis of literary works method including historical novels.

The informants are the people in the scope of the study, the people who are able to give information about the situation and the condition of research background. The research subjects or the informants are the History Education Department students contracting "Literaturein History Learning" lecture academic year of 2008-2009 with 40 students and the students contracting "The History of National Movement of Indonesia" with 80 students.

\section{Research Technique}

Data collecting techniques used in this research is observation, interview, questionnaires, and documentation. All these techniques are expected to be helpful in obtaining the data needed. Thus, this research would contain data in the form of quotation from the result of literary study, interview, outdoor-notes, photos, vidoetape record, private documentary, note/ memo, formal document and so on.

The researcher observed the forth semester students of History Education Department contracting The History of National Movement of Indonesia. There are 90 students (enclosed) contracting the lecture, consisting of two classes, class A and class $\mathrm{B}$. The researcher observed 32 times in both classes since February, 2010 until May, 2010. In the lecture, historical novel study correlated to the period of national movement of Indonesia is a mandatory task which has to be submitted before mid test. After mid test, there are two themes related to historical novels which are assigned to be group discussion material, they are; literature theme in national movement period and the problem of cultural development in the national movement period of Indonesia.

The interview would be done after the students submitted their assignment about the historical novel study (after mid test). The interview questions are designed to explain more about the students' understanding towards the unrecorded novels in written tasks. On the 11th May 2010, the researcher carried out the interview as the data triangulation from the first interview, document analysis, and questionnaires which have been dome on March 2010. The questions given are;

1. What is the position of historical novels in Historic? What is the relationship between literature and history?

2. How is the process while you are studying the novels?

3. What are the obstacles while studying the historical novels?

4. What do you think of your feeling about the novels?

5. What do you think about the author of the novels? Did the author have a new point of view about the figures of history or certain events of history?

6. How do you compare about novels to the text books; whether the figures, the content or the social setting?

7. The effect of novel analysis towards students' perception about history?

8. The students' perception about the use of historical novels in learning

9. Students' weaknesses in applying historical knowlege to analyze historical novels.

10. Students' weaknesses in applying literay theories to analyze historical novels. 
The novel study was carried out in group (each group consists of three persons) with totally 15 groups in class A and 16 group in class B. Each group had to study one different novel with the following guidance:

\section{Table 6.1 Students' Assignment Guidance}

The Assignment of the 'History of National Movement of Indonesia' Lecture Novel Study (point out the following elements).

1. Book identity

2. Author's biography and his/her point of view towards his/her era reality (his/her thought setting)

3. The intrinsic elements of the novel (theme, chapter, setting of time and place, plot)

4. The analysis (social setting, economical setting, political setting, the difference of fact and fiction described in the novel)

5. The comparison between textbooks (the historian's work about National Movement Era)

6. Values contained in the Novel

7. The novel relevance as a source of history learning (how to access novels into history learning)

Thus, the researcher would obtain about 31 document of students' assignment in historical novel study. In addition to this, the researcher obtained document of novel study from the lecture of "Literature in History Learning" as much as 60 documents of personal assignment and 10 document of group assignment. The researcher felt that total number of the document was enough as the analysis materials to understand how the history department students' perception towards the social reality described in those novels.

The questionnaires the researcher made were in the form of open questions and of multiple choices. The survey was required to find out: the informants' identity, the informants' reading habit, the students' understanding about the way to analyze historical novels, students' perception towards social reality in the novels, and students' perception about the application of novels in learning.

\section{Research Findings and Discussion}

The number of informants filling the questionnaires was 120 persons. Most of the informants were female (67 students) and the rest 53 were male. The informants came from twoacademicyears,year 2008; 80informants and year 2006 ; 40 informants. They came from four different classes; 40 persons from year 2008 were from class A, 'The History of National Movement of Indonesia' lectured by Encep Supriatna, M.Pd, and the other 40 persons were from class B, 'The History of National Movement of Indonesia' lectured by Drs. Ayi Budi Santosa, M.Si. Meanwhile from year 2006, consisted of class I and J, each of classes was taken 20 informants with 'Literature in Learning History' lectured by Dr. Nana Supriatna, M.Ed (20 persons), and Prof. Dr. Rochiati Wiriaatmadja, M.A (20 persons). From 120 persons who filled the questionnaires, 18 persons (named enclosed) were the informants intensively interviewed by the writer. The temporary informants' GPA ranged between 3,01-3,50, (46,7 \% ) and 2,51-3,00 (43,3\%). Meanwhile, only 7,5 $\%$ of the informants who have GPA ranged 
more than 3,50 (cum laude). Yet, there were also some informants who had GPA less than 2,5 (2,5\%).

\section{The Novels Studied by the Students}

The total number of novel analyzed by the students was 51 novels written by 35 authors (13 foreign authors and 22 domestic authors). The following are mentioned the title of the novels analyzed by the students. In the lecture of "Literature in Learning History", the students were free to choose the novels they were going to study, while in the lecture if "The History of National Movement of Indonesia", the students had to choose novels correlated to the lecture. It means that that the theme was limited only to the theme of the history of national movement of Indonesia. The title of domestic novel analyzed by the informants were; Kalah dan Menang, Rumah Kaca, De Winst, Salah Asuhan, Di Bawah Lindungan Kabah, Para Priyayi, Tenggelamnya Kapal Van Der Wijck, Robert Anak Surapati, Bumi Manusia, Burung-Burung Manyar, Student Hidjo, Anak Semua Bangsa, Layar Terkembang, Negeri Van Orange, Dian Yang Tak Kunjung Padam, Jejak Langkah, Larasati, Bumi Hangus, Malam, PahlawanPahlawan Yarmuk, Riau Berdarah, Gadis Pantai, Siti Nurbaya, Ken Arok Ken Dedes, TulipMerah Batavia, Gadis PermataBunda, Pembalasan Anusapati Tohjaya, Korupsi, Sebuah Lorong Di Kotaku, Ken Arok Ken Dedes, Perempuan Kembang Jepun, Bukan Pasar Malam, Sekali Peristiwa Di Banten Selatan, Harimau-Harimau, Misteri Harta Karun VOC, Jalan Raya Pos, Koela, and Langit dan Bumi Sahabat Kami. The titles of the foreign novels (interpreted) were; Robert Cowel Story, Sulaeman Queen Sheba, Khadijah, Ambisi Meraih Mahkota,
Sang Penakluk Andalusia, Yakuza Moon, My Salwa My Palestine, Don Quixeto, Kisah 47 Ronin, Uncle Tom's Cabin, Taj Mahal, The Al Chemist, and Twist.

\section{The Students' Ability in Historical Novels Study}

This section would describe the correlated materials with materials the students got and understood as well as the process of comprehending the novels they studied. This section would discuss about various results of analyses and students' understanding about the historical novels, namely; the relationship between in the novels, history and literature, facts and fictions in the novel, reality in the novels, and their perception about novel analysis. These data were needed to find out students ability in novels study and their point of view about those historical novels.

\section{The Students' ability in understanding the relationship between Literature and History}

In the following, various students' perceptions about the relationship between literature and history would be elaborated whether it was about the position of history in knowledge structure, the linkages between literature and history, and the position of historical novels as historical resources. From those data, the writer would be able to find out how far the students' understanding about fundamental of Historic.

a. Most of the students appraised that history as a part of social and humanities science, and only several students admitted it as a part of either social science only or humanities science only.

b. For the students, the linkages of history with literature occurred in the phase of 
historical research (historiography). In the historiography phase, a historian needed art elements while writing a story in order to be interesting to read.

c. Most of the students admitted that novels could be used as a historical resource. Students' perception about the capacity of novels to be used or not to be used as historical resource was not based on theoretical base and scientific arguments.

The students' perception differed from several historians' perception who viewed that there was a correlation between history and literature. According to Sjamsuddin (2008: 276), history as humanities science emphasized on creativity, emotion release, efforts to seek for values through creativity in composing literature or reading literary works. In the definition of history as humanities science, Gottschalk concluded that history was more on subscribed literature, meant that the existence of history inclined to "art", even though on one side he admitted that history was also a "science" (Supardan, 2008: 291).

It is true that the linkage of literature and history is close enough if it is seen in postmodernism perspectives. One of them is White's view (Sjamsuddin, 2007) who stated that history us a narration mastered by aesthetic conventions and closer to literature than to science. According to Purwanto (2006), as an imagined reality, history and literature could not be rigidly associated with only one side from both sides, associated with either literature or history only. Facts and fictions had no significant differences textually, it meant that history and literature could be associated to be entrenched in the same fields - language.

\section{The Students' Ability to Distinguish Facts and Fictions in novels}

Having studied students' perception in literature and history position, the writer needed to study students' perception in understanding the facts and fiction in historical novels. In students' view, facts in the novels existed in their social setting, culture, politic and economic setting. According to the students, fact could also exist in factual author's experience outlined in his/her novel (for example; the works of Nh. Dini and Sunaryo Basuki) and fiction was the story flavoring. The example of facts in social setting existing in the novels of Para Priyayi, Siti Nurbaya, Di Bawah Lindungan Kabah novels was the description about common law governing wedding matters including matchmaking matters, and their parents would be free from their responsibility after their children got married. In the novel of Para Priyayi, it was depicted Javanese custom in matchmaking, namely; the couple had to be equal or commensurate, educated, skillful and ductile, and he/she had to understand the etiquette to manage noble's household matters. Whereas in Pramoedya novel, it really depicted the nuance of feudalism culture in Javanese society in the colonial era.

The facts in the field of politic and economy, the students cited some example existing in the novel of De Winst, it was discrepancy of economy, De Jonge harsh politic and facts about the implementation of ethical politic in the novel of Bumi Manusia. The sinking of Van der Wijck ship on the 28th October, 1936 was a fact existing in the novel of Tenggelamnya Kapal Van Der Wijck. The fact of cultural phenomena was depicted from the culture of hierarchical 
bureaucracy in the novel of Gadis Pantai and the effect of Western education in the social life of Minang people in the novel of Salah Asuhan novel. Fact and fiction could also be distinguished from the author's note (foot note) included in some novels. In the novel of Di Bawah Lindungan Kabah novels, the students found a fact about the Hamka's pilgrimage in 1926, the pilgrimage of Cokroaminoto and Mas Mansur and also the authority transition in Mecca from Syarif Husein's control to Ibnu Saud's which made the hajj lane safer that triggered the booming number of people who wanted to be hajj.

From the students' view, fiction existed in story braid or plot. Fiction was also found more on the fictive characters. According to the students, fiction was used to dramatize an event. The form of fiction could be seen from the excessively passionate depiction from a historical event. Fiction was also seen from the language use or choice, it was a novel used figure of speech like hyperbole, personification, and very personal narration, by connecting facts with personal experience.

Nevertheless, according to the students, the differences between facts and fictions were not clear, it made facts and fictions differences difficult to identify unequivocally in the novels. The students' confusion towards facts and fictions in the novel could be seen from the fact that 100 informants who were able to mention historical facts, they could mention only one or two historical figures they knew, or they could mention only one or several events they were able to elaborate in history textbooks. None of the informants was able to elaborate at length or even to reveal critically the facts and the fictions existing in the historical novels.

\section{The Students' ability in Analyzing Reality (Social, Economical, Political, and Cultural Setting) in the novels}

Historical novels are romance telling an era in the history and trying to show and catch some spirit of the era (zeitgeist), manners and social condition of past time by elaborating in detail historical facts in order to be seemed realistic (Lindquist, 2008: 2). Paying attention to the characteristic of a good novel revealed by Wiriaatmadja (2003) and Djokosujanto (2001), it was then clear that historical novels must depict life honestly and accurately, it doesn't make any distortion towards historical facts, and contained historical facts existing from the beginning until to the end of the story, and the historical novels must be always faithful to the outline and time and place setting of history.

Mahmud Safei (2007) stated that literary works are said as a result of mixture painting of reality and imagination. It means that an author's experience, what he/she feels, hears, and sees is poured again into a written or oral story with language as its tool. However, his/her experience isn't displayed as it is. He/she has experienced a process; appreciation, interpretation, and evaluation. Through imagination, the process will arrive at an effort to give comprehension. This is the significance which is reflected by an author in the form of literary works. Fundamental principles from literary works formulation, whatever the kinds, are the expressions from experience plus imagination. Generally, literary creation is transcription of the author's journey of life who creates it, as a human who cannot be separated from the influence of era and place where he/she lives. (Hutagalung, 1967:19). 
In this section, the writer would present various students' perception about the reality depicted in the novels they were studying, they were mentioned below;

1. Majority of students appraised the society condition in historical novels they were studying was depicted honestly and accurately. However, many students did not know whether the society condition in those novels was depicted honestly and accurately or not.

2. The students appraised that the spirit of era was depicted in those novels.

3. The students appraised that the novels depicted reality which possibly happened and the setting of place details depicted were original. When asked deeper through interview, almost all of them then answered that they did not own enough knowledge about those cities, that made them doubt the existence of those cities, even more when the background of the novels took place overseas.

4. The students appraised that the novels they were studying elaborated the geographical condition and social condition in that era. Therefore, having studied the novels, they obtained the depiction of aspects of geographical and social condition of the society. Novel surely tended to explain the geographical and social condition as detail as possible in order to seem real and the readers inflamed to grow their imagination while reading those novels.

5. Majority of the students appraised that the conflicts depicted in the novels were real, yet many students appraised that some of the conflicts were real while some others were mirages.

6. Most of the students were able to determine that historical story existed in certain periodization of history. Yet, some of them considered that the novels could not be categorized into certain periodization of history. The students were confused whether the novels included into which periodization of history because several reasons, they were:

7. The novels didn't clearly explain the setting of time, like Salah Asuhan novel and Layar Terkembang novel which according to the students told about the national movement period, yet the social setting described like the Indonesian society nowadays, especially about women's position in social structure.

8. Most of the students faced difficulty in determining the periodization of foreign novels which they were studying. They felt that they did not have enough knowledge about the countries' history, like Yakuza Moon, Kisah 47 Ronin, Al Chemist and other novels. This would strengthen writer's argument about the weaknesses of students' historical knowledge mastery, including the comprehension of historical periodization.

Cuddon(Djokosujatno, 2001:2) revealed that historical figures in the novels could be the main or complement characters in chronological events representing a historical process, and it seemed that the convention of historical novels was limited to the continuous presence of figures and historical events only. Based on the students' study, they found that they knew some of historical 
figures in the novels they were studying. Yet, there were some students who did not find any historical figures and they appraised that the figures existing in the novels were only imaginary figures. The students, stating stated that in the historical novels there were found historical figures, appraised the author described the historical figures at length and there were only six students who regarded that the author did not describe the figures at length. Meanwhile, about the fictive figures existing in historical novels, the students appraised that those figure were in accordance with historical setting. Yet, many students answered that they did not know what indicated their difficulty to determine whether the depicted figures conformed or not with historical setting.

\section{The Students ${ }^{6}$ Ability in Analyzing the Authors of the Novels}

From the sociology of literature view, a litterateur did not live in an empty space. A novelist's works will be influenced by the wickerwork of existing social elements, the values he/she adopted - including his/her viewpoint toward reality, and it cannot be forgotten that a novelist will be influenced by literary development elements and the existing consensus in the authors' era. Thus, the understanding about novelists was important in analyzing novels and the analysis result would be showed how far students' critical thinking ability towards the novelists.

Most students viewed that the values was adopted by the novelists were depicted in their novels. But there were five students who appraised that those values were not depicted in the novels and twenty seven answered that they didn't know. In fact, the 27 informants, answering the latter, studied novels written by foreign authors, such as
Elie Wiesel, Ali Ahmad, Yosef Tugio, Roberto Cowel, Waheeda, Abdul Mun'im, Musthafa, Shoko thendo, Ibrohim Pawal, Miguel, Jhon Allyn, Harriot Beecher, Lan Fang, Jhon Shors, Paulo Coleho, and Charles Dickens. The students' reason in their difficulty to understand authors' value was because it was not enough to read only one of works of the authors to understand their values and their perspective. In their opinion, to find out the authors' mode of thinking and the values they adopted, they had to read other works.

According to the students' perspective, Sutan Takdir presented a lot of ideas to advance women and discussed a lot about culture philosophy leading to modernization and upheld the Western model of modernity. Therefore, according to the students, rational thinking flavored his novels because he liked Western concepts. His novels presented idealism to be a clue to social change into a democraticsocietyupholding humanequality and Sutan Takdir absolutely opposed the culture of feudalism.

The students considered that Pramoedya Ananta Toer was very leftist, even though he preferred to call his thought as "pramism". In the realm of literature, his works were included into socialist realism. Thus, according to the students, it was fair that in his novels, Pramoedya raised many issues about socialists and communists like equality or egalitarians and he tried to raise subalterns up, critics of social injustice, the importance to educate generations, to uphold democracy, and to love the country.

In students' study, Pramoedya dreamt of modern people who struggle for great ideas, spirit of universalism and a sole truth, as well as humanities struggle against evil power that never stopped. Pramoedya was viewed as an anti-oppression, aspired justice and had a 
vision about change through the corporation of the poor and the oppressed. For him, writing is a personal and national duty. It wasn't then astonishing that, in his novels, Pramoedya discussed al a lot about the life of 'grassroots' and tried to uplifted their lives which seemed to be neglected, criticized and highlighted the depravity of 'santri or students' who were not sensitive towards social problems, critic towards nobles' and feudal lives, justice, truth, and humanities, and criticized the governance of centric Javanese, criticized social discrimination in colonial era and stratification as well as difficult absolutism. Pramoedya's moral values to the youth was that the youth had to be able to run the governance honestly, free from any kinds of corruption, collusion and nepotism. According to him, corruption was not an individual phenomenon but politic social problem. The description of perfect society according to Pramoedya was democratic society, emancipation of woman, and anti-compression.

According to the students' view, in his novels, Abdoel Moeis criticized a lot about Western custom and values, and viewed Western and Eastern in cultural conflict perspective. In his novels, he criticized westernized and delirious bourgeoisie's behavior. Abdoel Moeis was extremely critical towards the impacts of ethical politic because it made the students were uprooted from culture and strayed from ancestral customs. Meanwhile, the students viewed Hamka owned Islamic reformer-based reasoning and romantic nationalist religious complexion. Hamka preferred to used his novels as his tools in cultural critic and propagandamedia. The social realitydepicted by Hamka in his novels was the occurrence of various irregularities creed (superstition, myth and heresy) and the most dauntless was to criticize the custom of Minangkabau people who regarded their tribes were the most important without thinking about the existence of other tribes.

Meanwhile, the students did not elaborate much about other 31 novelists, they only described it briefly. Even there were twelve novelists' values which were not exposed by the students. Henceforth, the students faced some difficulty to understand the mode thinking of the novelists and how their perspective affected their works.

\section{The Studnets' Perception about the Usage of Novels in History Learning}

From the interview finding, there were obtained some explanations which could be elaborated from the above table as follow;

a. Majority of the students appraised that historical novels could be used in history learning. Even though there were still a lot of students who doubted novels as history resource, they seemed to regard that novels could be used as a history learning resource,

b. There were three opinions about the usage of novels in history learning both at universities and at schools; they regarded it was important, less important, and textbooks were more important,

c. The students appraised that the usage of novels in learning was better used for school levels rather than universities level because the history learning in universities was more important to use text books, and

d. The importance of using novels both at schools and at universities depended on the need for history learning values and strategies to make learning more fun. In the following sections would 
be discussed about values contained in novels which could be conveyed to the learners.

\section{TheEffect of Historical Novel Analysis towards Students' Perception about History and History Learning}

Historical novels arouse respons not only intelectually but also emotionally. From the interview findings, documentation anaysis, observation and questionaries, it can be revealed that the analysis of historical novels had given new point of view about history. In the following would be conveyed what the writer had found from this research from what the students comprehended.

Students' study about historical novels made them be aware of the importance to see the role of forgotten grassroots or 'little people' in history. For instance, Anisa Ulfatiani, Arum Sekar Jati, Rinrin Desti Apriani, while studying Para Priyayi novel, conveyed about a figure of ordinary farmer named Sastrodarsono and his struggle in order to be a priyayi or a noble at the end. Ripa obtained information about children's lives during the war of independence while studying Sebuah Lorong di Kotaku novel. The awareness of the important roles of little people in history was also obtained by Reza Andriansyah after reading Harimau-Harimau novel. He thought that understanding history could be started from small events and little people. Similarly, while Putri Purwati was studying Langit dan Bumi Sahabat Kami novel, she appraised that little people also contributed big role in determining history movement.

\section{Historical Thinking}

Levstik dan Barton (1997: 91) stated that historical stories are powerpul cultural force because they are able to present historical interpretation by impressing way and directly impact towards the students' historical thinking. According to large majority of students, historical novels helped them establish their capability of explaining past events. Thestudentsappraising thathistorical novels didn't help them to explain past events stated that they didn't find historical facts in in the novels or they still doubted the truth of the historical fatcs. Meanwhile, most of the students appraised that historical novels helped them distinguish past, present and future. Some students answered that they didn't know and they reasoned that the novels they were analyzing used complicated or confusing plot (mixing plots).

The students' opinions about the impact of novels in forming their historical thinking are listed below:

a. Most of the students appraised that historical novels helped them identify the chronological time and helped them understand the continuity of history and shifting.

b. Historical novels helped the students to behave critically by helping them ask question thenovelscontentand evaluate history. Questioning the content of the novels commonly happened if the the content itself was different from or opposite to the content of textbooks.

c. Novels helped them to compare between historical narration in the novels and in the textbooks. From the document analysis, it was then found that the students were categorized into three categories; students who felt that novelsweremorehelpfulthan textbooks in understading historical events, students who felt that textbooks were better used than novel to understand history, and students who regarded 
noveks and textbooks could similarly be used to understand more about the histrory because both contained historical information elements.

The arguments used by the students who thought that textbooks were far more benefit than novels to understand history are listed below.

a. In a novel, facts could only be used to support the story and a novel could not be used as a primary resouce of history and it was not appropriate to be used as a reference to scientific research. Textbooks presented primary and more accurate data that it could be used as a resource of history learning and a resource of historical reserach.

b. Historical facts found in a novel were very limited that it could only be used as a textbook complementary. In a novel, there were many historical needed to be questioned, yet the values needed to understand.

c. The element of romance contained in a novel was to extravagant and its language was flavored a lot with metaphor. While in the textbooks, facts were presented in more detail.

d. In a novel, there were founds different facts from those of textbooks. For example, fact about Aurangzeb, depicted in Taj Mahal novel was like a terorists, meanwhile in the textbooks discussing about India's history, Aurangzeb was depicted as a pious, religious and earthy figure.

e. Textbook language didn't flow nor stimulated imagination; yet, textbooks gave more holistical understanding.

Meanwhile, the arguments of some students regarding that novels provided more excellences than those of textbooks are listed below: a. Novels and textbooks similarly discussed about urban lives, stratification, and feudalism, yet novels depicted them so descriptivelya and narratively which enlivened readers' imagination.

b. Novels were useful as a dulce et utile (entertaining as well as useful) and novels were far easier to be understood becausetheypresentedpersonalelement and emotion flavoring the history. The story line in a novel triggered curiousity and touched emotionally than that of in the textbook, thus it was easier to penetrated historical figures' thought and historical events.

c. Novels were more interesting because of the expertise to string words; thus, novels could bring into the certain era nuance. Novels enabled us to dive into historical figures' thought, novels were more touching emotionally than textbooks and triggered more curiousity.

d. Novels were more interactive and could be used as an alternative media in learning history to enhance students' imagination better than textbooks.

e. Novelsweredifferentfromtextbooks,for example Salah Asuhan novel presented more crticis about westernized life styke and Minang custom. Henceforth, novels highlighted more in social condition that novel deserved to be complementary information and an alternative media in history learning. Novels present different perspective about history from that of textbooks do.

\section{Historical Understanding}

Historical understanding is associated with the process of comprehension which is done by the students while analysing the 
novels. Historical stories, according to Egan (Levstik and Barton, 1997: 91) are always able to entangle people's response and interest towards certain historical events and they begin to understand more more about history (historical understanding). It was elaborated by Levstik and Barton (1997: 91) that "stories are, after all, generally more compelling reading than texbook". The effect of the novel study towards students' historical understanding can be seen from the following elaboration.

a. Historical novels help the students to understand more about the history, to obtainimportantvaluesinlife,tofeeland to enliven the figures, various conflicts and other human's problems, and to help in conceiving the process of social shifting in the society. Furthermore, in the students' perception, novels help them understand themselves and their family deeper, society history in their environment to help them to understand more about their national history.

b. Historical novels help the students as if they experienced the past events themselves and help them understand social culture. From the data, it can be concluded that historical novels help the students improve their historical understanding, it is to ease for them to understand and to comprehend history, to obtain to obtain important values in life, to feel and to enliven the figures, various conflicts and other human's problems, to help in understanding the process of social shifting in the society. Furthermore, in the students' perception, novels help them understand deeper themselves and their family, society history in their environment and help them to understand more about their national history.

\section{The establishment of Students' Attitude}

From the questioners and interview, information was obtained that majority of the students appraised the use of novels in history learning in university affected to the establishment of students personality. If we understand that personality in two categories, the way of thinking and behaving, thus there were some students who appraised that novels was give effect to the students' way of thinking and behaving and even some others fell that novels doesn't give effect to the students' way of thinking and behaving

From the interview, some factors were revealed that why didn't give effect to the establishment of students' personality in their way of thinking and behaving in the following;

a. The students felt that, to establish or to form their way of thinking and behaving, novels were not enough, and the students felt that they needed to read a lot of other novels in order to enrich their insight.

b. They felt they didn't read the novels seriously because they admitted the novels only their homework. Moreover, novels were only used as entertainment only.

Meanwhile, there were some factors why novels gave effect to the students' personality establishment in their way of thinking and behaving, they were;

a. The students were psychologically in the age of looking for their identity. The students found human ideal 
figures from the figures or characters presented in the novels. However, the students also understood that the figures or the characters in the novels were not perfect people and, in some cases, they tended to behave negatively. For example, the character of Minke in the tetralogy of Pramoedya who was depicted as a truly faithful warrior figure, yet he had weakness in his weak attitude to the woman. The students were inspired from the figures' great attitude presented in Hamka's novels.

b. The students were psychologically in the age of being so close to the world of romance. From their novels, the students could understand how to learn to love, to be loved, and be ready to suffer for their beloved ones. In addition, they obtained a moral value about ups and down in flowing the groove romance presented by the figures and the students felt that it also often happened to them.

c. Novels gave a lot of inspiration and spirit to be advanced and useful persons to many people. Novels truly often presented some figures in which their behavior brought them up to be a winner or a woward. Life for a young man was a struggle to realize idealism. Some students realized that this life was not only for self-struggle but also struggle for many people.

d. Thestudentsunderstoodtheimportance of filtering culture fom foreign country including Western. In several novels written by Abdoel Moeis were always depictd that the Western did not always brinng advances, sometimes it triggerred the occurence of identity crisis. Furthermore, the students were not alergic towards diversity, culture, race or religion.

\section{The Students' Perception about History Learning at Schools and Universities after Historical Novel Study}

There were some benefits felt by the students after studying novels, they are; enhance historical knowledge and information, view history from other sides excepts from textbooks, expand their imagination, and understood the spirit of era. There are some more benefits felt by the students even though the inensity hasn't regarded great, it was historical reference and resource, understood more psycologcal aspects of historical and social figures, feel that the learning is more fun than of from textbook, because it describes historical events more detailedy and growth creativitu and inspiration resource.

Besides, thosebenefits exposed reviously, from the result of interview, it was found that, in fact, novels provided some others benefit, they were;

a. Novel revealed more about historical information and was able to reenliven past event

b. Understanding more about the nature of success, failure, disappointment in various historical events that encouraged the student to think critically and brought inspiration as well as encouraged them to grow their imagination,

c. Values contained in the novels could be made as an appeal in learning history and the backgroudn could be used as a learning resouce,

d. Novel depicted the nuance and situation which were not depicted in 
textbooks that made it easier to explain about historical figures, to understand others' way and perspective of life,

e. Functioning as reading sources and stimulating reading eagerness as well as investigating hostory more deeply,

f. Understanding social, political, cultural, and economic setting in certain historical background; thus, novels could arouse awareness of history uniqueness and be absorbed in the atmosphere of emotion,

g. Train students' analysis skill by comparing the content of a novel to the content of a textbook and the students were stimulating to express historical events they got.

\section{The Data Analisys}

In this section, various analyses will be elaborated about the categorization of students' ability appreciating historical novels, their weakness in analyzing historical novels, and the efforts to enhance their ability in appreciating historical novels. The analysis in this section was based on the result of observation, questionnaires, interview, and documentation study which have been discussed at length in the previous section.

\section{The Categorizations of the Students' Ability in Appreciating Historical Novels}

In the previous section, it has been discussed about the ability of students majoring History to appreciate historical novels. From the data, the will categorized students into several types, i.e.; idealist type, skeptical type and pragmatic (realistic) type. Those categories have been made based on literary reception theory. As having been elaborated previously that literary reception is students' acquisition or perception and comprehension towards the novel they are studying (Teuw, 1984: 152). Students' perception would truly exist because, like Isser's opinion (Teuw, 1984: 152), a text could array readers' reactions to itself.

The categorization made by the writer are built upon the types of readers, appreciation levels, obtained impacts, existing intellectual were and emotional responses, applied approaches, the ability to dig historical information up, and values available in historical novels. The writer could generally explained that most of the History Education Department students in UPI were in the pragmatic/realistic category, and only a small fraction included into skeptic and idealistic categories. Theaim of making thesecategories was built upon the desire to improve more of History Education Department students' ability to appreciate historical novels. The writer made the ideal categories of how the students' should appreciate historical novels in order to be able to array the skeptic and pragmatic categorized students to be ideal categorized students.

By applying phenomenology approach, the writer digs up the students' perception, perspective, imagination, willingness, desire and also action occurring while they were doing historical novels study. The writer tried to explore their awareness structure in their experience while appreciating the novels in order to be able to explain the structure of awareness types ranging from perception, perspective, memory, imagination, emotion, eagerness, willingness, and also actions, both social and language form. The types of awareness categorized as idealistic, skeptic and pragmatic were students' perspective to the novels they are studying. For further details, it will be described below. 


\section{The Idealist Students}

The students belonging to idealist type are the students who were able to analyze novels not only arriving at the stages of engaging readers' feeling or emotional elements (engaging), conceiving character, setting, language and information contained in a novel (conceiving), and interpreting it (interpreting), but also arriving at the stages of judging, evaluating the characters and the quality of story as a whole. Idealist students referring to a literary appreciation according to Rusyana (1984: 322) belong to the second and the third appreciation level. Thus, besides the can engage their intellect, emotion and imagination while appreciating literature, the idealist students always ask to themselves about the meaning of experience the get about the messages conveyed by the authors and they also realize the relationship between literary works and the outside world, so that their comprehension and enjoyment can be done widely and deeply.

The fundamental difference between ideal and skeptic types, borrowing Rusyana's term (1984:322) is lied on the aspect of "more enjoying" not only to rely on mere intellectual response, not only to question, to analyze, but also to find the answer and to conceive deeper.. While according to Segers's opinion (2000), ideal tipy is experienced readers in appreciating literature and critical readers knowing more about "literary theory" that they are able to conceive the relationship between semantic and pragmatic. Ideal type students use deconstructivistic approach in seeing the text in the novels. Deconstructivistic approach, stated by Gilbert dan Vic (Supriatna, 2007: 183) views something reversely, and studies social events and discourse through various dimensions. This bears awareness that in the novels they find more prominent figures from ordinary people, little people, than those from great figures which often reveals in the textbooks.

Idealist students have certain characteristics from their ability to dig up historical information and available values in the novel, they are listed below:

1. They are able to explain the relationship between history and literature, thus they understand theoretical base of using historical novels in learning process.

2. They conceive the concepts of fact and fiction and they conceive them not as simply as usually revealed that fact is a truth and fiction is a lie. Fact for them is a reality and fiction is a "reality imitation" which has been touched by novelists' imagination and conception.

3. They are able to catch spirit of the era (zeitgeist), manners, and social, economic, politica and cultural condition in the past thus by analyzing novels theycan obtain someinformation about history.

4. They are able to obtain values adopted by the novelist depicted in their novels and they can associate them with the reality described by the authors. Furthermore, they are able to compare them with the description from the textbook written by historians.

5. They are able to understand and use novels in the history learning both at schools and at the universities.

6. Novels help form historical thinking and historical understanding.

7. Novels affect the formation of personality in the way of thinking and behaving by seeing ideal human figures in the figures presented in the 
novels, they can learn how to love, to beloved and to be ready to suffer for their beloved ones, and novels a lot of inspiration and spirit to be an advanced person and be useful for human being.

8. Novels provide a lot of benefits intellectually and emotionally. The intellectual benefit: to enrich historical knowledge and information, to see history from other sides which doesn't exist in textbooks, to develop imagination, to understand spirit of the era, historical reference and source, to understand more about psychological aspects of historical and social figures, to make the learning process more fun, to make it as a comparison resource from textbook, to give detail description of historical events, to train the students analysis skill by comparing the content of novels to the textbooks' and to cultivate the students' creativity and inspiration source. Emotional benefits are: to enliven again the past, to conceive the nature of success, failure, and disappointment in various historical events containedinthenovels, to stimulate the students' interest, and to investigate the history deeper and to arouse awareness of the uniqueness of history and to be absorbed in the emotional atmosphere.

\section{The Skeptical Students}

Skeptical students belong to the students categorized into implicit readers and Segers's category (2000). Implicit reading has a competence to appreciate literature and also own knowledge about history. As known by the writer, many of the students use historical approach in appreciating novels. Skeptical students are very dominant in their intellectual elements and from the analysis result, they only engage a bit or even not at all of their emotional elements in their novel study. Skeptical students do not use emotive approach to appreciate literature, an approach trying to find out elements which institute emotion or feeling in the form of beauty, entertainment, and pleasure. They question a lot about the historical elements available in the novels, such as events, figures or social, economical, political, and cultural setting described in the novels, yet most of them only end with a question.

Theyseenovelsbyusing conflictapproach especially in the works of Pramoedya Ananta Toer. Conflict approach is derived from Marxist's theory which see the society has been structure and divided into certain classed in conflict position. The application of conflict approach could be seen from their analysis from several novels, i.e.: Kalah dan Menang written by Sutan Takdir Alisjahbana and described the Pribumi struggle against imperialism and colonialisme Rumah Kaca, written by Pramoedya reviewed the economic gap and conflict about social classes between pribumi colonial authorities, and even in the novel, high levels pribumi were still lagging behind the colonial authorities. While in the novel of Bumi Manusia, it discussed a lot about inferior nobles who lived in culture dualisme (Western and Javanese). De Winst written by Afifah Afra showed us a lot about the description of social stratification of Indonesian society (Western, Foreign East, indigenous or pribumi) where in the era of the Dutch Colony. Para Priyayi written by Umar Kayam showed the conflict and suspense among classes caused by different ideology among the nobles, the abangans and the santri.

From their ability in digging historical information and values contained in them, skeptical students have the following characteristics: 
1. They questioned and doubted the linkage between literature and history because, according to them, history differed from literature. While according to them, literary works associated with history when literature told about a historical events or in the novel there found historical figures.

2. Thestudents stated that theythemselves questioned the truth of historical facts revealed by the novelists, yet they didn't have enough historical knowledge to ascertain.

3. They questioned the honesty and the accuracy of the description of historical figures, events, the condition of society (social, political, economical, and cultural setting) in the historical novels they were studying.

4. To understand values and the authors' way of thinking, it was not enough only to read only one work. According to them, to get the authors' mode of thinking and the values they adopted, the students had to read many other works.

5. Novels were only appropriately used to the levels of schools (Junior High School and Senior High School) and were not appropriately used to the levels of universities as it was better to use textbooks in the universities.

6. Novels helped them in forming historical thinking and historical understanding.

7. Novels didn't affect to the personality establishment in the way of thinking and behaving, because it was not enough to use only novels and the students needed to read many more novels in order to enrich their horizon.
8. Novels gave many significances intellectually and emotionally. Yet, according to the students, the intellectual significances were obtained more from textbooks than those from novels.

\section{The Pragmatic/Realist Students}

Pragmatic students are the categorized realist readers according to Segers's view (2000). Realist readers belong to the individuals who truly and originally read because they are not affected by literary theories. They read due to certain purposes, in the context of History Education Department students, they read only to fulfill their lecture course assignment. Therefore, their purpose to appreciate novels is to dig up historical information and the values contained in the novels. They only described their findings and even they didn't try to analyze and to interpret deeper. In Rusyana's category (1984: 322), pragmatical type belongs to first level readers, a person who experience existing experience in a work of art and he only engages intellectually, emotionally and imaginatively. The approach used by the students to study a novel as a text is liberal approach. The students' explanation who studied the novels presented and narrated a lot of great figures. This approach brought them into a conclusion that textbooks are far more important than the novels.

From their ability in digging historical information and values contained in a historical novel, pragmatic/realist students have the following characters:

1. They didn't know the relationship between literature and history and according to them it was not too important because analyzing 
a novel need not understand first the correlation between history and literature. For them, the linkage of history and literature lie on the phase of historical research (historiography) when a historian needed art elements to write historical stories in order to be interesting to read.

2. According tothestudents, the difference between facts and fictions were not so clear that it was difficult to identify fact and fiction firmly in a novel.

3. They did not have enough knowledge about the description of historical figures and events, the condition of the society (social, politic, economic, and cultural setting) that they doubted it. Yet, the most important for them was that the novels helped them obtain some description more than the textbooks could provide about certain historical events and figures.

4. Conceiving values adopted by the authors needed not analyze their novels directly, it was enough by analyzing other's analysis result or persons who were expert in the works of art.

5. The importance of using novels both at schools and at universities depended on the need to make the historical learning values and strategies to be more fun.

6. Novels helped in forming historical thinking and historical understanding.

7. Novels didn't affect to the personality establishment in the way of thinking and behaving, because they felt that they were not serious enough to read the novels and they read them only to complete their assignment. Furthermore, They made the novels as a mere entertainment.

8. Novels provided a lot of significances emotionally but not intelectually.

9. To understand more about the difference of ideal type ideal, skeptical type, and pragmatic type, the writer presented them in the comparison table below.

Tabel 6. 4 The comparison of Idealist Type, Skeptist type, and Pragmatic (Realist) Type

\begin{tabular}{|c|c|c|c|c|}
\hline No & $\begin{array}{l}\text { Thing com- } \\
\text { pared }\end{array}$ & Idealist Type & Skeptist Type & $\begin{array}{c}\text { Pragmatic (Re- } \\
\text { alist) Type }\end{array}$ \\
\hline 1 & Readers' response & $\begin{array}{l}\text { engaging, conceiving, in- } \\
\text { terpreting, judging }\end{array}$ & $\begin{array}{l}\text { engaging, conceiv- } \\
\text { ing, interpreting, }\end{array}$ & $\begin{array}{l}\text { engaging, conceiv- } \\
\text { ing }\end{array}$ \\
\hline 2 & Appreciation levels & $\begin{array}{l}\text { The second and the third } \\
\text { (intellectual, emotional } \\
\text { responses, and they enjoy } \\
\text { the literature better) }\end{array}$ & $\begin{array}{l}\text { The second } \\
\text { (dominanly intellec- } \\
\text { tual response) }\end{array}$ & $\begin{array}{l}\text { The first } \\
\text { (dominantly emo- } \\
\text { tional response) }\end{array}$ \\
\hline 3 & Readers' type & Ideal readers & Implicit readers & Realist readers \\
\hline 4 & Approaches used & deconstructivistic & conflict & Liberal \\
\hline 5 & $\begin{array}{l}\text { The Understand- } \\
\text { ing of Relationship } \\
\text { between Literature } \\
\text { and History }\end{array}$ & $\begin{array}{l}\text { Understanding theoreti- } \\
\text { cal base of using historical } \\
\text { novels in learning }\end{array}$ & $\begin{array}{l}\text { Questioning and } \\
\text { doubting the linkage } \\
\text { between literature } \\
\text { and history, because } \\
\text { according to them } \\
\text { history and litera- } \\
\text { ture were different }\end{array}$ & $\begin{array}{l}\text { It was not too impor- } \\
\text { tant because to ana- } \\
\text { lyze a novel needed } \\
\text { not understand first } \\
\text { the relationship be- } \\
\text { tween history and } \\
\text { literature }\end{array}$ \\
\hline
\end{tabular}




\begin{tabular}{|c|c|c|c|c|}
\hline 6 & $\begin{array}{l}\text { The Understanding } \\
\text { of facts and fictions }\end{array}$ & $\begin{array}{l}\text { Facts for them are reality } \\
\text { and fiction is "reality imi- } \\
\text { tation having been touched } \\
\text { by the novelists' imagina- } \\
\text { tion and conception. }\end{array}$ & $\begin{array}{l}\text { They themselves } \\
\text { question the truth } \\
\text { of the fact revealed } \\
\text { by the novelists, } \\
\text { yet they didn't have } \\
\text { enough historical } \\
\text { knowledge to ascer- } \\
\text { tain }\end{array}$ & $\begin{array}{l}\text { The difference be- } \\
\text { tween fact and fic- } \\
\text { tion was not clear }\end{array}$ \\
\hline 7 & Social reality & $\begin{array}{l}\text { They were able to under- } \\
\text { stand the spirit of era (zeit- } \\
\text { geist), manners and the } \\
\text { social, economic, political, } \\
\text { cultural conditions }\end{array}$ & $\begin{array}{l}\text { Theyquestioned alot } \\
\text { about the historical } \\
\text { elements available } \\
\text { in the novels like the } \\
\text { events, authors and } \\
\text { the social, economic, } \\
\text { political, and cultur- } \\
\text { al setting depicted in } \\
\text { the novels, yet most } \\
\text { of them ended with } \\
\text { questions }\end{array}$ & $\begin{array}{l}\text { The most impor- } \\
\text { tant for them was } \\
\text { the novel helped } \\
\text { them to obtain the } \\
\text { description more } \\
\text { than from textbooks } \\
\text { about certain his- } \\
\text { torical events and } \\
\text { figures }\end{array}$ \\
\hline 8 & $\begin{array}{l}\text { Values adopted by } \\
\text { the authors }\end{array}$ & $\begin{array}{l}\text { They were able to obtained } \\
\text { values presented by the } \\
\text { authors }\end{array}$ & $\begin{array}{l}\text { To understand val- } \\
\text { ues and the authors } \\
\text { way of thinking, } \\
\text { reading one novel } \\
\text { was not enough }\end{array}$ & $\begin{array}{l}\text { It was enough to } \\
\text { analyze other's/ex- } \\
\text { pert's analysis re- } \\
\text { sult. }\end{array}$ \\
\hline 9 & $\begin{array}{l}\text { The use of novels in } \\
\text { the learning }\end{array}$ & $\begin{array}{l}\text { Understand and enable } \\
\text { them to use novels in his- } \\
\text { torical learning both at } \\
\text { schools and universities }\end{array}$ & $\begin{array}{l}\text { Novels were ap- } \\
\text { propriately used in } \\
\text { schools level learn- } \\
\text { ing }\end{array}$ & $\begin{array}{l}\text { The need of histori- } \\
\text { cal learning values } \\
\text { and strategies in or- } \\
\text { der to make learn- } \\
\text { ing more fun }\end{array}$ \\
\hline 10 & $\begin{array}{l}\text { The impact of nov- } \\
\text { els }\end{array}$ & $\begin{array}{l}\text { Novels impacted to the } \\
\text { personality establishment }\end{array}$ & $\begin{array}{l}\text { Novels didn't impact } \\
\text { to the personality es- } \\
\text { tablishment because } \\
\text { it was not enough } \\
\text { only to read novels, } \\
\text { the students needed } \\
\text { to read many more } \\
\text { novels to enrich } \\
\text { their horizon }\end{array}$ & $\begin{array}{l}\text { Novels didn't im- } \\
\text { pact to the person- } \\
\text { ality establishment } \\
\text { because they felt } \\
\text { that they were not } \\
\text { serious enough to } \\
\text { read the novels, they } \\
\text { read novels only to } \\
\text { complete their as- } \\
\text { signment }\end{array}$ \\
\hline 11 & $\begin{array}{l}\text { The significances of } \\
\text { novels }\end{array}$ & $\begin{array}{l}\text { Novels provide a lot of sig- } \\
\text { nificances intelectually and } \\
\text { emotionally }\end{array}$ & $\begin{array}{l}\text { Intellectual signifi- } \\
\text { cances from text- } \\
\text { books exceed from } \\
\text { novels. }\end{array}$ & $\begin{array}{l}\text { Novels provide a } \\
\text { lot of significances } \\
\text { emotionally but not } \\
\text { intelectually }\end{array}$ \\
\hline
\end{tabular}

\section{The Students' Weaknesses in Analyzing Historical Novels}

In this section, the writer will elaborate various results correlated with students' weaknesses in analyzing historical novels. The writer will elaborate various cases, for example: students' weaknesses in understanding the relationship between literature and history, students' weakness in conceiving about facts and fictions in the novels, students' conceiving weakness about reality (social, economic, political, and cultural setting) in the novels, students' conceiving and analyzing weakness about the use of novels in history learning. 


\section{The Students' weaknesses in understanding the relationship between literature and history}

Fundamental weaknesses which are seen from the students cannot be explain and the linkage between literature and history. Students' perception about the reliability of historical novels used as a historical source do not based on their understanding in the theoretical base and scientific base. The students were confused when they explained the position of history from humanities side. Even, they were confuses over the definition of humanities, and their explanation was not to obvious nor appropriate, moreover in explaining the relationship between history and literary in the scope of humanities.

\section{The Conceiving Weakness about Fact and Fiction in novels}

In students' view, fact and fiction in a novel existing in the following things:

1. found in social, cultural, political and economic setting,

2. writers' real experience poured into a novel,

3. fact and fiction could also be used from the authors' note (foot note) availabel in several novels which were always made in those novels, and

4. fact could only be used as a story support in the novels.

While about fiction, the students appraised that in novels contained the following:

1. Stories seasoning,

2. Fiction existed in the braid or plot of the novel story,

3. Fiction was used to dramatize an event,
4. Fiction could be seen in the passionate depiction of a historical event, and

5. Fiction could also be seen from the usage of its language, a novel which used many figures of language like hyperbole, personification and personal narration, it was to relate fact with personal experience.

The followings are the writer's analysis about the students' weakness in analyzing fact and fiction in some cases:

1. The difficulty to distinguish between fact and fiction that made the students were difficult to identify fact and fiction firmly in a novel,

2. The difficulty showed the existence of historical distortion in the novles they were studying, yet in the other side they believed that the novelists were impossible to conduct any lie in their works,

3. The detail of the story made them believe that the story was true, yet they still questioned it academically,

4. The students were not able to elaborate at lenght or even to critically revealed facts and fiction available in the novels,

5. Their difficulty to determine whether the depicted figures were based on the historical setting,

6. The students were not able to give the example of facts in the novels they were analyzing,

7. The students were not able to show where the suitability of novels contents and those of textbooks.

The Students' weakness in conceiving about the Reality (Social, Economic, Political, and Cultural Setting) in Novels 
In the following were listed some of the students' weaknesses found by the writer while the students were analyzing the reality in novels.

1. The students didn't know whether the condition of the society in the novel was depicted accurately and honestly.

2. The students appraised that the novels depicted the reality which " might" happen and the detail of the place described was original or not, but they didn't have enough knowledge about the cities that they doubted their existence, moreover if the setting took place abroad.

3. Most of the students were able to determine whether the historical story in the novel happened in the certain periodization of history. Most of the students faced difficulty while determining the periodization of foreign novels. They felt that they didn't have enough knowledge about the countries history, like novels of Yakuza Moon, Kisah 47 Ronin, Al Chemist, etc.

4. The students appraised that some of the presented conflicts were real and some others were only mirages. It seemed that the latter indicated they were confused to determine the realness of the conflicts depicted in the novels.

5. In their analysis, the students were only able to reveal the geographical condition and the society condition without following up the analysis further neither comparing to the textbooks which discussed similar cases nor analyzing how and why the novelists such social condition.

6. The students faced some difficulty to see whether the depicted figures were historical figures or mirage figures and appropriate or not with the historical setting.

\section{TheStudents'WeaknessinConceiving and Analyzing about Novelists}

The following are listed some of the studnets' weaknesses found by the writer while analyzing the students'comprehension and analysis to the novelists:

1. The students conveived less about the elements of subjectivity in every novel. They hadn't realized that the novelists had values or ideology which affected their perspective towards the reality written in their novels.

2. The students had weaknesses in conceiving the about the authors' mode of thinking and how their perspective affected their works. In students' mind, to obtain the authors' mode of thinking and the values they adopted, the students had to read a lot of other works.

3. The students faced some difficulty to reveal the values owned by the novelists.Most of the students didn't eloborate much abput the authors and they only described the authors briefly. Suprisingly, there were 12 of the novelists whose values were not revealed by the students.

4. Their evaluation towards novelists was seen from their skill to present the story in their novels rather than from the accuracy of facts and reality setting they exposed. The students appraised that a novelist who told a historical story well would be regarded that the novelist had conducted historical research before and had had so good historical knowledge that the historical facts were regarded accurate. 
5. The students faced some difficulty to study the values owned by foreign novelists incluing their way of thinking towards reality. The students appraised that novels written by foreign authors told historical story well, but they were confused and they didn't know whether the authors conducted historical research or not.

\section{TheStudents'ConceivingWeaknesses about the Use of Novels in History Learning}

In the following are listed about several students' weaknesses found by the writer while analyzing students' comprehension and analysis towards the use of novels in histrory learning:

1. The students hadn't yet understood that th use of historical novels in history learning was one of solutions to solve the problems of history learning both at schools and at universities.

2. The students appraised that the use of novels in learning was better applied at school levels than at universities because historical learning at universities needed textbook the most

The Efforts to Improve Students' Ability in Appreciating Historical Novels

\section{Conceiving the Concepts of Literary Appreciation}

It should be understood by the students that literary appreciation was an activity to read or to enjoy copyright taste in a form of text and direct performance as well. Literary appreciation can also be indirectly in a form of activity to learn about literary theories, to read articles related to literature in magazines or newspapers, to learn about books or essays discussing and giving evaluation towards literary works, and to learn literary works (Amninudin, 2009: 36). Henceforth, it can be understood that the occurrence of various students' weaknesses in appreciating novels was started by their incomprehension about the meaning of appreciation itself. The students were merely busy reading the novels and then tried to find the elements assigned to them. They didn't understand that appreciating literature can also be done by learning theories of literature or learning the novels they are reading. It isn't surprising then that their duty seems only to summarize the novels they read.

Rusyana (1984) stated that appreciation of literature done by the readers must fulfill starting requirements, i.e., earnest and assiduous eagerness, good attitude towards literature, and an interest to appreciate literature. It was strengthened by E.E.Kellet (Amninudin, 2009: 37) that while reading a literary work, he always tries to present seriousness, but with a jovial mood.The growing of this serious attitude is important to read literary works because literature is born from the power of an author's inner contemplation that to understand his work, it needs the readers' contemplation power, while on the other hand, literature is an actual and imaginative art because it can give an spiritual entertainment and satisfaction to the readers.

\section{Improving Reading Culture and History Knowledge}

Historical knowledge has a great correlation with reading culture. In the previous section, it has been elaborated that one of factors triggering the lowness of historical comprehension and knowledge among the students is due to their low 
interest in reading and learning motivation. Sjamsuddin (2008) stated that one of the problem in learning history in universities is that reading culture hasn't yet penetrated into every circle, whereas, "reading" is one of absolute requirement in learning history. This opinion was strengthened by Arif (2008) exposing some obstacles obstructing in learning achievement of historic subject, it is reading interest and ability among the learners.

The lowness of students' historical knowledge causes their inability to explain the correlation between literature and history. Whereas, understanding the linkage of history and literature is required to make the students understand the position of romance or novels in history science. Furthermore, this understanding is needed as a scientific base in studying historical novels both as a historical source and as a source of historical learning, and in making the students understand the goal of novel study as a historical source and as a source of historical learning.

The study of literary works and historical novels has to be understood first from the meaning of history from humanities. According toSjamsuddin(2008:276), history as a humanities emphasizes on creativity, emotion release, effort to find values from creativity by writing or reading literary works.The topics discussed in humanities is not merely related with narration, but it correlated to the use of language and rhetoric. Therefore, a comprehension about history as a humanities will enable the students to understand that the linkage of history and literature is in the use of language (discourse) and rhetoric (art of talking or art of affecting).

The impact of opinion rejecting the relationship between literature and history is that history cannot be equated to literature and it impacts to that the literature cannot be studied to be a source of history nor as a source of historical learning. Therefore, before the students are arrayed to analyze a novel, it is suggested that they have to understand about the linkage of literature and history as a whole package especially in the paradigm of postmodernism; so the students truly understand the significance of a historical novel in historic and the purpose to conduct some studies in those novels. Meanwhile, the second opinion tries to post novels or romance while being made as historical resource in a historiography, the data used is usually uncorrelated to detailed matters about the explanation of place, time, or chronology of an event $(5 \mathrm{~W}+1 \mathrm{H})$, instead of being used to obtain some description about awareness of the era or spirit of the era growing at the time. According to the second opinion, comprehending historical novels aims at gaining a description of a social shifting process and social manner or value taking place in the society.

The understanding about the correlation of history and literature must be conceived by the students before analyzing the novels in ordertocomprehend thesignificanceofnovels or romance in Historics and understand the purpose of novel study both as a historical source and a historical learning source. Hence, after they have truly understood the relationship between literature and history - especially if they understand the views supporting the existence of history and literature relationship, the students will obtain the scientific base of the importance of historical novels as a historical source and a historical learning source. In the writer's mind, the opposing opinion cannot be neglected because it is considered to be important enough and inevitably in critical 
history learning, the students can compare between historical narration in a historical novel and textbooks.

The lack of historical knowledge makes the students difficult to distinguish facts and fictions. Actually, the difficulty to distinguish between facts and fiction is a common weakness of Indonesian society, especially those out of literary competence. For them, literary works are similar to history and science. Literary works must be understood that they don't belong to the real reality because works of art are creative - imaginative activities, tasted reality, and representation of the reality itself. Enough historical language correlates to the fact one knows. Therefore, if one reads Bumi Manusia novel setting on the National Movement, historical facts at the time will be used to analyze the novel.

\section{Improving the Students' Knowledge and Comprehension towards Theories of Literature}

Throguh the mastery literature theories, the students will be able to understand, to appreciate, and to interprete literary works. Furthermore, they will be able to evaluate the the novels quality and the era reality which bears the novels. However, the obstacles are that the theories of the literature haven't been learned by the students yet.

From previous data, it can be obtained some information that the students haven't got enough materials about literay theories. Yet, comprehensioan about theories of literature is needed as a 'knife' to analyze literary works. A literary work would not be abletobeconceived, appreciated, interpreted, or evaluated perfectly without deeper understanding about literary theories. The understanding towards the novel is required to obtain a description of a social shifting process and value because the development of a novel roots from the social shifting and values (Esten, 1981: 40). There are some functions of literary theories, i.e.; review and assess the high or low value of a literary work, as a guide and comparison to the writing of literary works, and to know and understand the era bearing it (Esten, 1981: 40). The following would be elaborated examples the writer could find how to apply the theories of literature to analyze a novel. Besides, the writer would give a way to analyze novels with availabeliterature theories, which would be limited on the theories of postcolonial, literary sos]ciology, and socialist realism.

\section{Conclusion}

The research finding conclude four cases: first, historyandlearning aspectsconceived by the students were about the linkage between history and literature, novels as a historical source, the difference of facts and fictions in the novels, the comparison between novels and textbooks, values adopted bythenovelists and perspective towards reality, social, political, cultural, and economic setting, values contained in novels and their relevance with history learning as well as the impact of historical novels to the students found in their perception about the role of little people in history, the establishment of historical thinking and historical understanding, and the establishment of students' personality. Second, reviewed from students' ability in appreciating novels, they were categorized into three categories, i.e.; idealist, skeptist, dan pragmatist students. Third, the students have some weaknesses in analyzing historical novels correlated with their understanding in the relationship between literature and history, their comprehension about facts an fictions in novels, their comprehension about 
the reality in novels, their comprehension and analysis about the novelists, and their comprehension about the use of novels in learning history. Forth, students' ability to appreciate novels could be improved by enhancing their comprehension in the concepts of appreciation, reading culture, historical knowledge and comprehension in the theories of literature.

\section{REFERENCES}

Abdulah, T. (1985). Ilmu Sejarah dan Historiografi (Arah dan Perspektif). Jakarta: Gramedia.

Alisjahbana, S.T. (2008). Kalah dan Menang. Jakarta: Dian Rakyat

Alwasilah, A.C. (2008). Pokoknya Kualitatif. Jakarta: Pustaka Jaya

Aminuddin (2009). Pengantar Apresiasi Karya Sastra. Bandung: Sinar Baru Algensindo

Ariyanto, Yos. (2008). Milan Kundera, Adam Malik, dan "Proyek Lupa". avaliable in http blog.liputan6.com [online]. 1 Agustus 2013.

Aslinda dan Leni. (2007). Pengantar Sosiolinguitik. Bandung: Refika Aditama

Beach and Marshal. (1991). Teaching literature in The Secondary School. Orlando: Harcout Bracejavanavi.

Benjamin. (1991). A Student Guide to History.New York (USA): St. Martin Press

Borries, Bodo von (2000). Methods and Aims of Teaching History in Europe: A Report on Youth and History, dalam Knowing Teaching \& Learning History: National and International Perspectives (Eds. Stearns, P.N., Seixas,P., Wineburg,S.). New York: New York University Press
Budianta, M. (2008). Representasi kaum Pinggiran dan Kapitalisme. Dalam buku Sastra Indonesia Modern (Kritik Postkolonial). Jakarta. Yayasan Obor Indonesia

Budiman, M. (2008). Masalah Sudut Pandang dan Dilema Kritik Postkolonial. Dalam buku Sastra IndonesiaModern(KritikPostkolonial). Jakarta. Yayasan Obor Indonesia.

Cahyani, I. (2005). Kemampuan Mendongeng Para Guru dalam meningkatkankemampuan Berbahasa Anak. Dalam buku Membaca Itu Indah (Pemikiran dan Penghormatan terhadap Drs.H.Zulkabir. Bandung: UPI Press:

California State Board of Education (2000).History-Social Science Content Standards for California Public Schools: Kindergarten through Grade Twelve. Sacramento: California Department of Education

Carr, E.H. (1961). What Is History. New York: Penguin Book

Cooper, H. dan Dorr, N. (1995). Race comparisons on need for achievement: a meta analytic alternative to Graham's Narrative Review. Review of Educational Research, 65, 4:483-508.

Creswell, J.W. (1998). Qualitative Inquiry and Research Design: Choosing Among Five Traditions. London: Sage Publications.

Damono, S.D. (2009). Novel Sastra Indonesia Sebelum Perang. Jakarta: Depdikbud

Darling-Hammond, L. (1996). The right to learn and the advancement of teaching: research, policy, and practice for democratic education. Educational Researcher, 25, 6:5-17.

Djahiri, H.A.K. (1990). Menulusuri Dunia Afektif; Lab.PPKN UPI. 
Djokosujanto, A. (2001). Novel Indonesia: Konvensi, Bentuk, Warna dan Pengarangnya. Jakarta : Lembaga Penelitian Universitas Indonesia.

Durachman, M. (2003). Kajian Prosa Fiksi Indonesia. Bandung. Jurdik Bahasa dan Sastra Indonesia

Egan, K. (1979). Memory, Imagination and Learning: Connected by the Story. New York: Oxford University Press.

Endratna. Sastra dan Novel, samasama Imajinatif?. avaliable http:// edratna.wordpress.com/2007/12/23/ sastra-dan-novel-sejarah-sama-samaimajinatif. [online]. 15 April 2009.

Escarpit, R. (2008). Sosiologi Sastra, Jakarta: Yayasan Obor Indonesia

Esten, M. (Ed). (2008). Menjelang Teori dan Kritik Susastra Indonesia yang Relevan. Bandung: Penerbit Angkasa.

Esten, M. (1981). Sastra Indonesia dan Tradisi Subkultur. Bandung: Penerbit Angkasa.

Farid, H. (2008). Pramoedya dan Historiografi Indonesia. Dalam buku "Perspektif Baru Penulisan Sejarah Indonesia. Jakarta: Yayasan Obor Indonesia

Faruk. (2002). Novel-Novel Indonesia Tradisi Balai Pustaka 1920-1942. Yogyakarta: Gama Media.

Foulcher, K. dan Toni, D. (2008). Sastra Indonesia Modern (Kritik Postkolonial). Jakarta. Yayasan Obor Indonesia

Garcia, E.E. (1993). Language, culture, and education. Review of Research in Education, 19:51-98.

Given, B. K. (2002). Brain Based Teaching. Bandung: Kaifa.

Gottschalk, L. (1985). Mengerti Sejarah. Jakarta. UI Press

Hakam, K. A. (2000). Pendidikan Nilai. Bandung: CV Maulana
Hamka.(1963). Tenggelamnya Kapal Van Der Wijjck. Jakarta. Bulan Bintang Hasan, S.H. (1996). Pendidikan Ilmu Sosial. Jakarta: Dirjendikti, Depdikbud Republik Indonesia.

Hatley, B. (2008). Postkolonialitas danm Perempuan dalam Sastra Indonesia Modern. Dalam buku Sastra Indonesia Modern (Kritik Postkolonial). Jakarta. Yayasan Obor Indonesia.

Hermawan, S. (2003). Kompleksitas Penggunaan Teks Sastra sebagai sumber Kajian Sejarah: Catatan dari Kajian Hikayat bandjar J.J.Ras. Makalah tidak dipublikasikan

Hertz, S. K. Using Historical Fiction in The History Classroom. tersedia di www. yale-new haven.edu[online]. 15 April 2009

Hill, W.F. (2009). Theories of Learning (Teori-teori Pembelajaran, Konsepsi, Komparasi, dan Signifikansi). Bandung: Nusa Media.

Hidayat, Bagja. (2009). Apabila Sejarah Menemukan Wajah. Avaliable in www. ruangbaca.com .[online]. 1 Agustus 2010.

Hunter, T. (2008). Indo sebagai Orang Lain. Dalam buku Sastra Indonesia Modern (Kritik Postkolonial). Jakarta. Yayasan Obor Indonesia

Isjoni. (2007). Pembelajaran Sejarah pada Satuan Pendidikan. Alfabeta: Bandung.

Jabrohim (Ed). (2002). Metodologi Penelitian Sastra. Yogyakarta: Hanindita

Jakubowski,C. (2002). Teaching World History: Problems and Promises Faced by Young Teachers. World History Bulletin. XVIII, 2.

Jarolimek, J. (1986). Sosial Studies in Elemetary Eduction. New York (USA): Macmillan Publishing. 
Kelly, D. Using Literature to Teach History: An Eric/ChESS Sample. tersedia di http://www.oah.org/pubs/magazine/ literature/kelly.html.25 Mei 2009. [online]. Diakses tanggal 15 April 2009 Kartodirdjo, S. (1992) Pendekatan Ilmu Sosial dalam Metodologi Sejarah, Jakarta: Gramedia.

Kartodirdjo, S. (1982). Pemikiran dan Perkembangan Historiografi Indonesia. Jakarta: Gramedia

Kuntowijoyo. (1995). Pengantar Ilmu Sejarah. Yogyakarta: PT Tiara Wacana.

Kuntowijoyo. (2005). Metodologi Sejarah. Yogyakarta. PT Tiara Wacana

Kuntowijoyo. (2008). Penjelasan Sejarah. Yogyakarta. PT Tiara Wacana

Levstik, Linda S and Keith C. (1997). Doing History. New Jersey (USA): Lawrence Publisher

Levstik,L.S. (2000). Articulating the Silences: Teachers' and Adolescents' Conceptions of Historical Significance, dalam Knowing Teaching and Learning History: National and International Perspectives, Knowing Teaching and Learning History: National and International Perspectives, ed. Stearns,P.N., P. Seixas, dan S. Wineburg.

Lee, P.J. (1984). Learning History. Liverpool (Britain): Heineman Educational Book

Lindquist,T. (1995). Seeing the whole through social studies. London: Heinemann

Lindquist, T. (2008). Why and How I Teach with Historical Fiction. tersedia di http www.teacher.scholastic.com [online]. Diakses tanggal 15 April 2009.
Lincoln, Y.S. \& E.G. Guba. (1985). Naturalistic Inquiry. Beverly Hills: Sage Publications

Mahayana, M.S. (2009). Fakta Dan Fiksi : Pertalian Sastra Dan Sejarah. Avaliable in http mahayana-mahadewa. com. [online]. Diakses tanggal 1 Agustus 2010.

Maier, H. (2008). Suara Gagap dan Pintu yang Berderit (Tulisan Pramoedya dalam Bahasa Melayu). Dalam buku Sastra Indonesia Modern (Kritik Postkolonial). Jakarta. Yayasan Obor Indonesia.

Marjohan. (2009). School Healing (Menyembuhkan Problem Sekolah). Yogyakarta: Pustaka Iman Madani.

Massofa. (2009). Aliran Sastra. Avaliable in http. massofa.wordpress.com. [online]. 1 Agustus 2013.

Moleong, L. J. (2006). Metode penelitian Kualitatif. Bandung: Rosda

Muhammad, R. (2008). Sastra dan Sejarah. Avaliable http. www. pawonsastra.blogspot.com. [online]. 15 April 2009.

Nasution, S. (1996). Metodologi Penelitian Naturalistik Kualitatif. Bandung: Tarsito.

Purwanto. (2006). Gagalnya Historiografi Indonesia Sentris. Yogyakarta: Penerbit Ombak

Ratna, N.K. (2008). Postkolonialisme Indonesia Relevansi Sastra. Yogyakarta: Pustaka Pelajar.

Respati, T. (2009). Sejarah: Sekilas Pandang. Avaliable in http. tedirespati. blogspot.com. [online]. Diakses tanggal 1 Agustus 2010.

Robertson, I. (2009). Misteri Pikiran Manusia. Yogyakarta: Gerailmu. 
Rusyana, R. (1984. Bahasa dan Sastra dalam Gamitan Pendidikan. Bandung:Diponogoro.

Said, E. (2001). Orientalisme. Bandung: Penerbit Putaka

Sarup, M. (2008). Postrukturalisme dan Posmodernisme. Bandung. Jalasutra.

Samekto. (1998). Ikhtisar Sejarah Kesusasteraan Inggris. Jakarta: Daya Widya

Segers, R. (2000). Evaluasi Teks Sastra, Sebuah Penelitian Eksperimental Berdasarkan Teori Semiotik dan Estetika Resepsi. Yogyakarta: Adicita.

Sharma, S.K. (2008). Teaching of History . Lotus Press (New Delhi, India)

Sjamsuddin, H. (2007). Metodologi Sejarah. Yogyakarta: Ombak

Sjamsuddin, H. (2008). Pembelajaran

SEJARAH: Refleksi dan Prospek.

Dalam Sejarah Sebuah Penilaian (Refleksi 70 Tahun Prof. Dr. H.Asmawi Zainul, M.Ed. Jurdik Sejarah UPI: Bandung.

Sugito, Z.R. (2008). Mistifikasi Novel.

Harian Jawa Pos tanggal 18 Mei 2008.

Suharno. (2009). Membudayakan

Penulisan Novel. Avaliable. staff. undip.ac.id. [online]. Diakses tanggal 1 Agustus 2010.

Sumantri, E. dan Sofyan, S. (2007). Pendidikan Nilai Kontemporer. Bandung: Citra Praya.

Supardan, D. (2008). Pengantar Ilmu Sosial. Jakarta: Bumi Aksara

Supriatna, N. (2007). Rekontruksi Pembelajaran Sejarah Kritis. Historia Utama Press. Bandung.

Supriatna, N. (2000). Pengajaran Sejarah Yang Konstruktivistik. Historia; Jurnal Pendidikan Sejarah 11 (3).
Surur, M. Mengais Realitas dalam Novel. Harian Jawa Pos tanggal 30 Maret 2008.

Sutherland, H. (2008). Meneliti Sejarah Penulisan Sejarah. Dalam Nordholt (Ed). Perspektif Baru Penulisan Sejarah Indonesia. Jakarta. Yayasan obor

Sutikno,M.S.(2007).PendidikanSekarang dan Masa Depan (Suatu Reflekasi untuk Mewujudkan Pendidikan yang Bermakna. NTP Press: Mataram.

Tadjudin, M. (2004). Kumpulan Terjemahan Karya Sastra Rusia. Bandung: PT Alumni

Tarigan, H.G. (1995). Dasar-Dasar Psikosastra. Bandung; Angkasa.

Tickell, P. (2008). Cinta di Masa Kolonialisme (Ras dan Percintaan dalam Sebuah Novel Indonesia Awal) Dalam buku Sastra Indonesia Modern (Kritik Postkolonial). Jakarta. Yayasan Obor Indonesia

Toer, P.A. (2001). Bumi Manusia. Hastra Mitra

Toer, P.A. (1996). Anak Semua Bangsa. Hastra Mitra

Toer, P.A. (1999). Arok Dedes. Hastra Mitra.

Toer, P.A. (2003). Realisme Sosialis dan Sastra Indonesia. Jakarta: Lentera Dipantara

Weiner, R.G. (2001). History: Teaching and Methode. Texas Tech University

White, H. (1985). Metahistory: The Historical Imagination In nineteenthCentrury Europe. London: The Jhon Hopkins University Press

Wilson,S.M. dan Wineburg,S.S. (1993). Wrinkles in time and place: using 
WILDAN INSAN FAUZI,

Novel Study in Learning History (Descriptive Analytical Study of the Ability of the History Education Departement Student in Appreciating Novel.

performanceassessmenttounderstand the knowledge of history teachers. American Educational Research Journal, 30, 4.

Wineburg, S. (2006). Berpikir Historis: Memetakan Masa Depan, Mengajarkan Masa Lalu. Jakarta: Yaysan Obor Indonesia.
Winkel, W.S.(1987). Psikologi Pengajaran. Jakarta: PT Gramedia.

Wiriaatmadja, R. (2002). Pendidikan Sejarah, Sikap kebangsaan, identitas nasional, sejarah lokal, masyarakat multikulktural. Historia Utama Press: Bandung.

Wiriaatmadja, R. (2009). Sastra dalam Pembelajaran Sejarah. Makalah. Tidak dipublikasikan. 